Sains Malaysiana 50(8)(2021): 2309-2318

http://doi.org/10.17576/jsm-2021-5008-14

\title{
Vancomycin Loaded Alginate/Cockle Shell Powder Nanobiocomposite Bone Scaffold for Antibacterial and Drug Release Evaluation
}

(Perancah Tulang Biokomposit-Nano Alginat/Serbuk Cengkerang Kerang yang Mengandungi Vankomisin untuk Sifat Antibakteria dan Penilaian Pembebasan Dadah)

\author{
Su Wen Yuan, Jacinta Santhanam, Ng Shiow Fern \& B. Hemabarathy Bharatham*
}

\begin{abstract}
Bacterial infection and biofilm formation is a major concern in orthopaedic implants and bone reconstructive surgery complications that may be addressed with localized drug delivery system. The potential use of a fabricated nanobiocomposite bone scaffold using alginate and nano cockle shell powder for drug release and antibacterial properties was investigated. Vancomycin loaded bone scaffolds were fabricated with 3 and 5 wt\% vancomycin, respectively, while a non-drug loaded scaffold was used as controls. The mineralization of the scaffolds using simulated body fluid (SBF) as well as biofilm formation were evaluated using microscopic observations. Drug release study and antimicrobial activity of the eluent from each sampling period was tested for growth inhibition of Staphylococcus aureus and Staphylococcus epidermidis for a period of 21 days. Significant difference of cumulative amount of vancomycin eluted from scaffolds loaded with $5 \mathrm{wt} \%$ vancomycin compared to $3 w t \%(p<0.05)$ were noted. Eluent from both groups showed inhibitory effect against bacterial strain tested for 21 days. The findings are further supported with histological observations of reduced biofilm formation by Staphylococcus epidermidis on surface of 5 wt $\%$ vancomycin loaded scaffolds compared to control scaffolds. Basic mineralization studies conducted showed no alteration in drug loaded scaffolds characteristics compared to control scaffolds. Findings from this study indicates antibacterial properties can be conferred to the fabricated bone scaffold with successful incorporation of vancomycin with potentials to be used for local drug delivery application.
\end{abstract}

Keywords: Antibacterial; bone scaffold; drug elution; nano cockle shell; vancomycin

ABSTRAK

Jangkitan bakteria dan pembentukan biofilem merupakan komplikasi utama dalam implantasi ortopedik dan pembedahan pembinaan semula tulang yang boleh ditangani dengan penghantaran dadah secara langsung dan setempat melalui peranti implan. Penyelidikan ini mengkaji pembebasan dadah dan aktiviti antibakteria elusi dadah daripada perancah tulang alginat/serbuk cangkerang kerang yang difabrikasi dengan 3 and $5 \%$ bt vankomisin. Untuk tujuan perbandingan, perancah tulang tanpa vankomisin difabrikasi sebagai kawalan. Aktiviti mineralisasi perancah dalam larutan simulasi cecair badan (SBF) dan pembentukan biofilem pada permukaan perancah diperhatikan dengan kajian mikroskopi. Kajian pembebasan dadah dijalankan dengan merendamkan perancah tulang dalam larutan SBF sebelum menilai jumlah elusi dadah pada tempoh masa tertentu. Aktiviti antibakteria elusi dadah terhadap Staphylococcus aureus dan Staphylococcus epidermidis telah dikaji melalui pembentukan zon perencatan selama 21 hari. Hasil kajian menunjukkan perbezaan yang signifikan pada jumlah elusi dadah dengan jumlah dadah yang dikesan daripada perancah tulang yang difabrikasi dengan $5 \%$ bt vankomisin lebih tinggi daripada $3 \%$ bt $(p<0.0 .5)$. Elusi daripada keduadua kumpulan perancah tulang menunjukkan kesan aktiviti antibakteria terhadap kedua-dua strain bakteria selama 21 hari. Hasil ini dibuktikan lagi dengan pemerhatian histologi yang menunjukkan pengurangan pembentukan biofilem Staphylococcus epidermidis pada perancah $5 \%$ bt vankomisin. Pemerhatian SEM juga menunjukkan tiada perubahan terhadap ciri-ciri pembentukan mineral pada permukaan perancah yang difabrikasikan dengan dadah berbanding perancah kumpulan kawalan. Hasil kajian ini menunjukkan perancah tulang alginat/serbuk cangkerang kerang yang difabrikasi dengan vankomisin menunjukkan ciri-ciri antibakteria dan berpotensi untuk dibangunkan dalam aplikasi sistem penghantaran dadah.

Kata kunci: Antibakteria; nano kulit cengkerang; pembebasan dadah; perancah tulang; vankomisin 


\section{INTRODUCTION}

Porous biodegradable bone grafts both from synthetic and natural origins have thus been gaining popularity as a replacement of the conventional methods of bone grafting in recent years. Biomaterials are one such naturally occurring choice that are widely used in the fabrication of bone scaffolds in tissue engineering and cell-based therapies (Zhao et al. 2011). These scaffolds are intended to provide a template possibly mimicking the functions of the extracellular matrix in addition to providing the needed structural support for the formation of new cells and tissues (Gutiérrez-Prieto et al. 2019; Mouriño et al. 2010). Bone scaffolds ideally should consist of a porous structure $>100 \mu \mathrm{m}$ to support cell penetration, growth of new tissues and vascularization (Saravanan et al. 2011) and is a major criteria that highly influences the osteogenic properties of the material (Abbasi et al. 2020). Approximately 10\% of bone graft procedures performed are compromised by bacterial infection, making it an on-going challenge in successful bone graft transplantation (Johnson \& García 2015). The bacterial strains commonly associated with implantation infections are Staphylococcus aureus and Staphylococcus epidermidis and are often found to infect patients through blood, open fractures and medical devices such as catheters (Krishnan et al. 2015). Implantation infection often begins with bacterial adhesion, a process highly influenced by environmental factors, bacterial properties, surface properties of the implant material and the presence of serum or protein tissue. There are several types of bacteria, especially Staphylococcus epidermidis that displays a defence mechanism against hosts immune system by secreting mucus upon adhering to an implant's surface thus protecting it from antibiotic therapy and cellmediated defence mechanism (Ribeiro et al. 2012).

Local delivery of drug by incorporating drug into bone scaffolds provide an attractive alternative in prevention of post-operative infections and inflammation after implant transplantation (Gentile et al. 2015). Bone scaffolds that serve as a drug delivery system has many advantages in delivering high concentration of drugs to the implant site. This can prevent drug concentration from fluctuating when transmitted through the blood vessels as well as any side effects from systemic administration of drugs that requires the use of higher doses (Channasanon et al. 2017). In this study, attempts were undertaken to incorporate vancomycin into the formulation of a biomaterial-based alginate/cockle shell powder nanobiocomposite bone scaffold as well as to study the potentials of the scaffold in drug delivery application. Vancomycin is a broad spectrum antibiotic which is widely used for the treatment of Staphylococcus infections (Yang et al. 2011). The use of alginate and nano cockle shell powder in the fabrication of the nanobiocomposite bone scaffold has been extensively studied in the recent years. The scaffold has shown excellent morphological structure and cellular responses towards bone cells (Bharatham et al. 2014) and the calcium contained in the cockle shell acts as an osteogenic stimulant capable of promoting cell attachment, proliferation, and growth of osteoblast (Ahmad et al. 2019). The deposition of nano cockle powder on the surface of the scaffold matrix has been highlighted in various microscopic studies and is a major contributing factor to the mineralization property of the scaffold as well as cellular interaction for osteoconduction as reported in previous studies (George et al. 2019). Biomaterials capable of undergoing mineralization have been well demonstrated to promote and enhance osteoblast interactions for bone regeneration ( $\mathrm{Wu}$ et al. 2020), therefore, changes to the scaffolds characteristic in regards to its ability to undergo mineralization upon being loaded with drugs is also highlighted in this study.

\section{MATERIALS AND METHODS}

\section{NANOBIOCOMPOSITE SCAFFOLD FABRICATION}

Bone scaffolds were fabricated by dissolving $0.3 \mathrm{~g}$ alginate in $6 \mathrm{~mL}$ of deionized water with subsequent addition of $0.7 \mathrm{~g}$ of nano cockleshell powder gradually at room temperature until a homogenous solution was formed. Vancomycin was then added into the mixture with 3 and $5 \mathrm{wt} \%$. 50\% citric acid solution was then added at different volumes until a desirable mouldable consistency was obtained. The material was then moulded into custom made cylindrical mold and allowed to set at $37{ }^{\circ} \mathrm{C}$ for $24 \mathrm{~h}$ in order to form the scaffolds. Scaffolds with no vancomycin incorporated were fabricated as control groups for comparison.

\section{DRUG ENCAPSULATION EFFICIENCY STUDY}

Encapsulation efficiency studies were conducted according to Krishnan et al. (2015). Scaffolds fabricated with vancomycin were powdered and soaked in $5 \mathrm{~mL}$ of PBS solution prior to be centrifuged at $8000 \mathrm{rpm}$ for 15 min. Presences of vancomycin in the supernatants were evaluated using spectrophotometer at $280 \mathrm{~nm}$ in triplicate 
and the concentration was determined based on a standard curve. The drug encapsulation efficiency was calculated using the formula herewith:

Drug Encapsulation Efficiency(\%) $=\frac{\text { Amount of Drug Encapsulated }}{\text { Amount of Drug Added }} \times 100$

\section{DRUG RELEASE STUDY}

Drug release study was conducted based on modified methods of Cao et al. (2017) and Zhang et al. (2012). Scaffolds were immersed in $10 \mathrm{~mL}$ of simulated body fluid (SBF) and incubated at $37^{\circ} \mathrm{C}$. The elution sample was taken at $1,5,12$, and $24 \mathrm{~h}$ as well as on days 3,6 , $10,14,18$, and 21 . During each sampling period, $1 \mathrm{~mL}$ of the elution sample was stored in the microcentrifuge tube and replaced with fresh simulated body fluid (SBF). Vancomycin concentration of eluted samples were determined by spectrophotometer at $280 \mathrm{~nm}$ in triplicate and was further used for bacterial inhibition studies.

\section{BACTERIAL INHIBITION STUDY}

Bacterial inhibition studies were performed on Staphylococcus aureus and Staphylococcus epidermidis grown in Mueller Hinton broth using the disc diffusion method. Both bacteria were incubated at $37{ }^{\circ} \mathrm{C}$ in growth medium and the culture was adjusted by spectrophotometric measurement at $625 \mathrm{~nm}$ to provide a final density of $1.0 \times 10^{8} \mathrm{CFU} / \mathrm{mL}$ in broth. $100 \mu \mathrm{L}$ of each bacterial strain were spread on Mueller Hinton agar in triplicates, respectively, prior to be placed for culturing with $6 \mathrm{~mm}$ diameter filter papers containing $10 \mu \mathrm{L}$ of the elution samples obtained from the drug release study. The agar plates were then incubated at $37^{\circ} \mathrm{C}$ overnight and the diameter of the inhibition zone on the agar plates were measured in millimetres (Isa et al. 2016).

\section{BIOFILM FORMATION STUDY}

Biofilm formation study was conducted using Staphylococcus epidermidis by incubating drug containing scaffolds and control scaffolds in $50 \mathrm{~mL}$ Luria broth which contain $1.0 \times 10^{6} \mathrm{CFU} / \mathrm{mL}$ bacteria. The conical flasks were shaken at $37^{\circ} \mathrm{C}, 80$ times per minute for $24 \mathrm{~h}$ using an incubator shaker. Bone scaffolds were then removed and washed with phosphate buffer solution (PBS) thrice to remove unattached bacteria's (Punyani et al. 2007) prior to be preserved for light microscopy examination.

\section{MINERALIZATION STUDY}

Mineralization study was performed on the formulated scaffold by immersing the scaffolds in simulated body fluid for $24 \mathrm{~h}$ prior to be preserved in $2.5 \%$ glutaraldehyde for scanning electron microscope (SEM) observation.

\section{STATISTICAL ANALYSIS}

All experimental data were expressed as mean \pm standard error mean (SEM) and quantitative results were analysed using independent T-test with significant value of $\mathrm{p}<0.05$.

\section{RESULTS AND DisCUSSION}

\section{NANOBIOCOMPOSITE SCAFFOLD FABRICATION}

Table 1 shows the texture obtained when different volumes of citric acid is added during the fabrication stage. The use of $30 \mu \mathrm{L}$ of citric acid was found to be most ideal in producing a mouldable texture for scaffold production. As discussed by Luong et al. (2016), bone scaffolds that can be moulded into appropriate shape and size according to the injured area can reduce the operation time as well as patient discomfort. Citric acid acts as a hardening agent that works by reducing the compressive strength at the initial stage of fabrication prior to increasing the mechanical strength of the scaffolds at the final stage during the hardening process (Dorozhkin 2011). The use of excessive citric acid causes difficulties in moulding of the scaffolds whereas insufficient amount of citric acid produces paste-like texture which would increase setting time tremendously in addition to compromising its mechanical properties.

\section{DRUG ENCAPSULATION EFFICIENCY}

Figure 1 shows the analysis of drug encapsulation efficiency between bone scaffolds fabricated with 3 and $5 \mathrm{wt} \%$ vancomycin. The drug encapsulation efficiency refers to the percentage of drugs successfully incorporated into the scaffold during its fabrication stage. From the study, it was noted that no significant differences in drug encapsulation efficiency was found with the use of 3 or $5 \mathrm{wt} \%$ drugs although the later showed slight reduction comparatively. This may be due to the interaction between the carboxyl group of the alginate polymer and the amide group of vancomycin which are involved in formation of the bonds. When the concentration of vancomycin 
increases, the carboxyl group of alginates which can interact with the amide group of vancomycin becomes lesser thus reducing the amount of drugs binding (Lecaroz et al. 2006). Since the amount of alginate used in the fabrication stage of both scaffolds are the same, the saturation of drug binding could be achieved with the lower dose of drugs for the given formulation.

\section{DRUG RELEASE STUDY}

Figure 2 shows the amount of drugs released from the scaffolds fabricated with 3 and $5 \mathrm{wt} \%$ vancomycin when placed into simulated body fluid (SBF). The cumulative release of vancomycin was found to be high on the first few days of the study prior to reaching a peak concentration on day 10 before declining gradually until day 21 . The peak concentration of vancomycin released from scaffolds fabricated with $3 \mathrm{wt} \%$ vancomycin on day 10 was 10.77 $\pm 1.42 \mathrm{mg}$ whereas a significantly higher release of 17.71 $\pm 0.85 \mathrm{mg}$ was noted with scaffolds fabricated with 5 $\mathrm{wt} \%$ of vancomycin. Significant increase $(\mathrm{p}<0.05)$ of cumulative drug release between both scaffold group were also noted on days $1,6,14$, and 21 . The high amount of vancomycin detected at the first few days of the study points to a favourable outcome towards the prevention of bacterial infection and biofilm formation. Post-surgical infection has the highest tendency to occur within $6 \mathrm{~h}$ postimplantation (Gimeno et al. 2015), the release of higher concentration of drugs in a short period of time reduces the duration for the drugs to be available at the implant site thus possibly conferring an immediate bacterial eradication effect and subsequent bacterial biofilm formation on the surface of the implant material (Cao et al. 2017). The results also showed that the amount of vancomycin released increased with vancomycin concentration used possibly due to increase in concentration gradient between the drug from the scaffold and surrounding simulated body fluid. This pattern was also found in the study of Abdelfattah et al. (2016), who investigated drug release profile from bone scaffolds that was made up of chitosan. The high amount of vancomycin released indicated this drug can cover larger area of the implant site, thereby protecting the surrounding tissues from bacterial infections and reducing the risk of implant failure. In this study, vancomycin release from the scaffolds were detected until day 21 indicating that the process of release occurred over a period of time after the initial burst release pattern observed. This is an important factor for the treatment of bacterial infection especially osteomyelitis as well as in preventing occurrence of recurrent infections throughout the recovery period, given the fact that $20-30 \%$ of recurrent infections were shown to lead to morbidity and mortality (del Pozo et al. 2018; Leekha et al. 2011). In a previous literature, the drug release profiles were reported to be highly dependent on a scaffold's architecture such as its porosity and material's degradation rate (Costa 2015). The material composition used in the formulation of the nanobiocompostie for this study has been previously reported to have excellent porosity of above $70 \%$. The degradation of the scaffold material was also reported to be highly dependent on the amount of alginate that contributes to the structural stability that is highly influenced by the uptake of fluid from its surroundings (Hemabarathy et al. 2014). Breakage in alginate network linkage occurs with the uptake of fluid which is deduced as a possible contributing factor to the release of drugs that was incorporated into the scaffold material. These findings further justify the ideal characteristic of the formulated scaffold as reported in the previous studies to endure a sufficient degradation time to ensure a continuous drug release profile for a longer duration.

TABLE 1. Scaffold fabrication formulation and the texture observed

\begin{tabular}{lllll}
\hline $\begin{array}{l}\text { Alginate } \\
\text { powder }(\mathrm{g})\end{array}$ & $\begin{array}{l}\text { Nano cockle shell } \\
\text { powder }(\mathrm{g})\end{array}$ & $\begin{array}{l}\text { Deionized water } \\
(\mathrm{mL})\end{array}$ & $\begin{array}{l}50 \% \text { citric acid } \\
(\mu \mathrm{L})\end{array}$ & Texture \\
\hline 0.3 & 0.7 & 6 & 200 & Non pliable \\
0.3 & 0.7 & 6 & 100 & Non pliable \\
0.3 & 0.7 & 6 & 50 & Non pliable \\
0.3 & 0.7 & 6 & 30 & Mouldable \\
0.3 & 0.7 & 6 & 20 & Runny paste \\
\hline
\end{tabular}




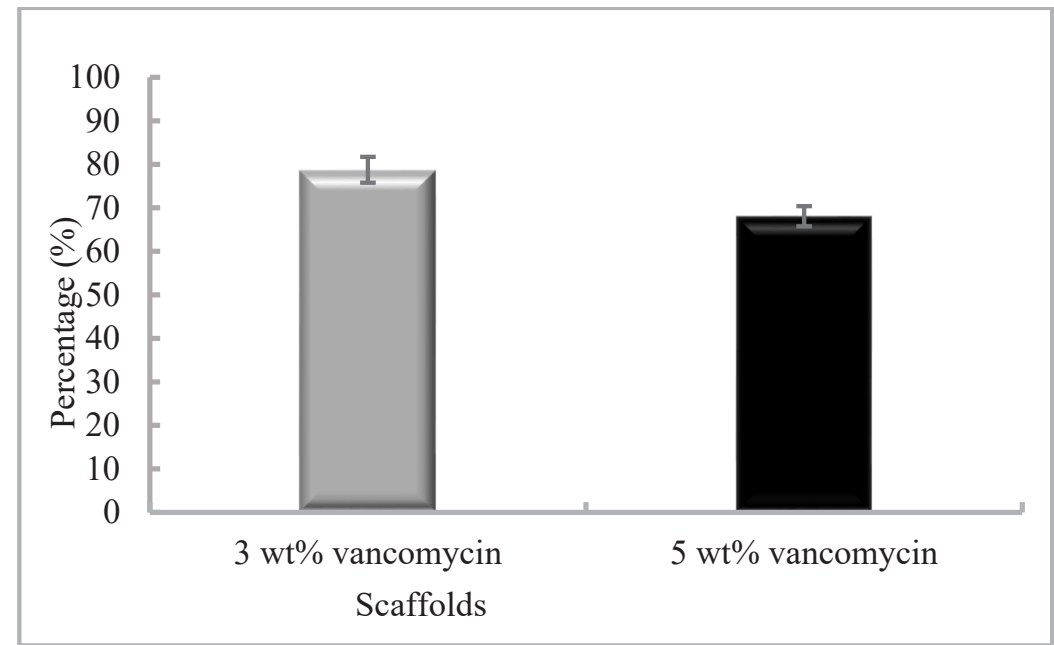

FIGURE 1. Analysis of drug encapsulation efficiency between bone scaffolds fabricated with $3 \mathrm{wt} \%$ error mean (SEM), $\mathrm{n}=3$

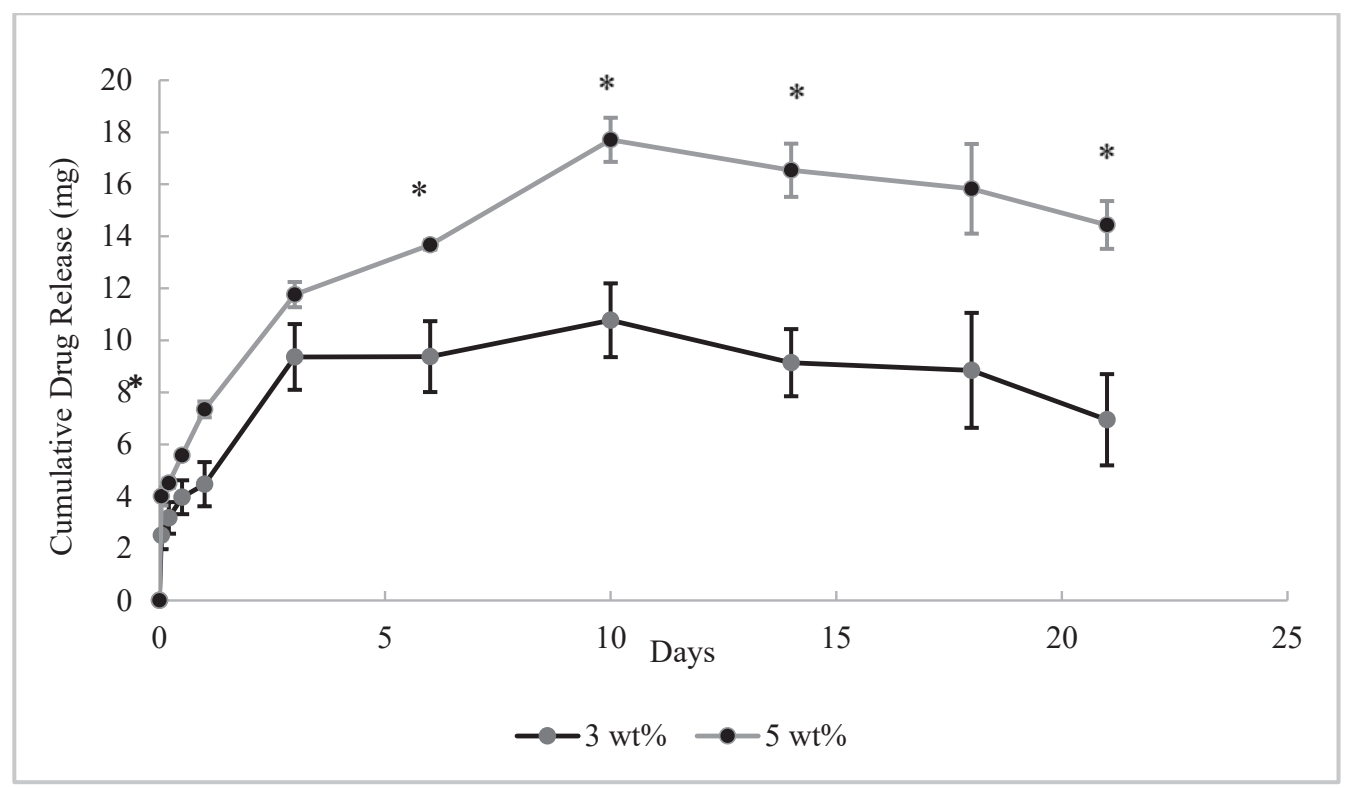

FIGURE 2. Cumulative drug release from scaffolds fabricated with 3 and $5 \mathrm{wt} \%$ vancomycin. Data described as mean \pm standard error mean (SEM), $\mathrm{n}=3 . * 5 \mathrm{wt} \%$ vancomycin loaded bone scaffolds vs $3 \mathrm{wt} \%$ vancomycin loaded bone scaffolds $(\mathrm{p}<0.05)$ 


\section{BACTERIAL INHIBITION STUDY}

In this study, drug elution from the fabricated scaffolds were tested for antibacterial activity against Staphylococcus aureus and Staphylococcus epidermidis, the most common pathogens that forms biofilms on implant devices (Montanaro et al. 2011). Table 2 shows the significant difference in diameter of inhibition zone against Staphylococcus aureus in $5 \mathrm{wt} \%$ vancomycin loaded scaffold on day $10(13.67 \pm 0.33 \mathrm{~mm})$ and day $18(11.67 \pm 0.33 \mathrm{~mm})$ compared to $3 \mathrm{wt} \%$ vancomycin loaded scaffold which was $11.67 \pm 0.33 \mathrm{~mm}$ and $9.67 \pm$ $0.33 \mathrm{~mm}$ on day 10 and day 18 , respectively at $\mathrm{p}<0.05$. While for Staphylococcus epidermidis, there was significant difference of inhibition zone between 3 and 5 $\mathrm{wt} \%$ vancomycin loaded bone scaffolds observed at 12 th hour, day $10,14,18$, and 21 at $p<0.05$. Findings from this study showed an antibacterial property of all eluted samples from the scaffolds throughout this study with the diameter of the inhibition zone found to be proportionate to the concentration of vancomycin. The inhibitory effects of the eluted drug were also found to be more significant towards Staphylococcus epidermidis compared to Staphylococcus aureus possibly due to the less virulent and less pathogenic nature of Staphylococcus epidermidis as compared to Staphylococcus aureus (Cheung et al. 2010).

\section{HISTOLOGICAL OBSERVATION OF BIOFILM FORMATION}

Based on the results of bacterial inhibition studies, biofilm formation study was conducted on Staphylococcus epidermidis using histological evaluation. Figure 3 shows presence of biofilm and multiple colonies of bacteria on a non-drug loaded control scaffold as compared to $3 \mathrm{wt} \%$ vancomycin scaffolds while absence of bacterial colony and biofilms were noted with the $5 \mathrm{wt} \%$ vancomycin scaffolds. Absence of bacterial growth and biofilm formation on scaffold surfaces in $5 \mathrm{wt} \%$ vancomycin loaded scaffold and the reduced number of colonies observed in $3 \mathrm{wt} \%$ vancomycin scaffolds further supports the drug release and bacterial inhibition study in the effectiveness of drug incorporation into the fabricated scaffold. A drug-dose relationship could be observed with complete inhibitory effect being observed with the use of a higher concentration of drug. Vancomycin could have potentially eradicated the adherence and colonisation of the bacteria onto the scaffold surface by altering the composition of bacterial peptidoglycan and inhibiting the formation of bacterial cell wall (Kohanski et al. 2010).

\section{MINERALIZATION STUDY}

A simple mineralization study was performed on scaffolds fabricated with the higher dose of $5 \mathrm{wt} \%$ vancomycin, in comparison with a non-drug loaded scaffold. Although high amounts of vancomycin released at the beginning is effective in eradicating bacteria colonisation, the possibility of it to counteract the effectiveness of bone regeneration process is still possible (Parent et al. 2016).

TABLE 2. Diameter of inhibition zone between scaffolds fabricated with 3 and $5 \mathrm{wt} \%$ vancomycin against Staphylococcus aureus and Staphylococcus epidermidis

\begin{tabular}{lllll}
\hline Days & \multicolumn{2}{l}{ Staphylococcus aureus } & \multicolumn{2}{l}{ Staphylococcus epidermidis } \\
\hline & $3 \mathrm{wt} \%(\mathrm{~mm})$ & $5 \mathrm{wt} \%(\mathrm{~mm})$ & $3 \mathrm{wt} \%(\mathrm{~mm})$ & $5 \mathrm{wt}^{\mathrm{o}}(\mathrm{mm})$ \\
\cline { 2 - 5 } $1^{\text {st }}$ hour & $10.00 \pm 0.00$ & $11.33 \pm 0.33$ & $10.33 \pm 0.33$ & $11.67 \pm 0.33$ \\
$5^{\text {th }}$ hour & $11.00 \pm 0.00$ & $12.00 \pm 0.00$ & $11.67 \pm 0.67$ & $13.33 \pm 0.33^{\mathrm{b}}$ \\
$1^{\text {th }}$ hour & $12.00 \pm 0.33$ & $12.33 \pm 0.33$ & $12.67 \pm 0.33$ & $14.33 \pm 0.33^{\mathrm{a}, \mathrm{b}}$ \\
Day 1 & $12.33 \pm 0.33$ & $12.33 \pm 0.33$ & $13.33 \pm 0.33$ & $14.67 \pm 0.33^{\mathrm{b}}$ \\
Day 3 & $12.33 \pm 0.00$ & $13.00 \pm 0.00$ & $13.67 \pm 0.67$ & $14.67 \pm 0.33^{\mathrm{b}}$ \\
Day 6 & $13.00 \pm 0.00$ & $13.00 \pm 0.00$ & $14.33 \pm 0.33$ & $15.00 \pm 0.00^{\mathrm{b}}$ \\
Day 10 & $11.67 \pm 0.33$ & $13.67 \pm 0.33^{\mathrm{a}}$ & $11.67 \pm 0.33$ & $14.00 \pm 0.00^{\mathrm{a}}$ \\
Day 14 & $10.67 \pm 0.33$ & $12.00 \pm 0.58$ & $10.00 \pm 0.58$ & $13.00 \pm 0.58^{\mathrm{a}}$ \\
Day 18 & $9.67 \pm 0.33$ & $11.67 \pm 0.33^{\mathrm{a}}$ & $10.33 \pm 0.88$ & $13.67 \pm 0.33^{\mathrm{a}, \mathrm{b}}$ \\
Day 21 & $9.00 \pm 0.58$ & $10.67 \pm 0.33$ & $8.00 \pm 0.58$ & $11.00 \pm 0.58^{\mathrm{a}}$ \\
\hline
\end{tabular}

${ }^{\mathrm{a}}$ - $5 \mathrm{wt} \%$ vancomycin loaded bone scaffolds vs $3 \mathrm{wt} \%$ vancomycin loaded bone scaffolds ( $\left.\mathrm{p}<0.05\right)$. ${ }^{\mathrm{b}}-5 \mathrm{wt} \%$ vancomycin loaded bone scaffold in Staphylococcus epidermidis vs $5 \mathrm{wt} \%$ vancomycin loaded bone scaffold in Staphylococcus aureus $(\mathrm{p}<0.05)$ 
Therefore, the mineralization study was carried out using stimulated body fluid to observe any alteration in the mineralization characteristics of the scaffolds. Ability to undergo mineralization is a well-known contributing factor to the increase in osteoconductivity of an implant material (Rodriguez et al. 2014). Figure 4 shows SEM micrograph of mineral apatite deposition on the surface of both non-drugs loaded control scaffold and $5 \mathrm{wt} \%$ vancomycin scaffold which proved drug incorporated scaffolds did not show alteration in its ability to undergo mineralization activity when treated with stimulated body fluid. This observation shows that the osteoconductivity of scaffolds incorporated with vancomycin is likely to be compromised in regard to facilitating new bone tissue formation. A previous study on CaP coated PLGA microparticle composites for drug delivery showed the mineralized material was able to undergo a controlled disintegration of the polymer enabling it to produce a controlled drug release effect (Matsubayashi et al. 2018). In a recent review article, it is notable to mention that the authors did conclude that the mineralization properties of a scaffold not only support osteogenesis but in addition, can be used to facilitate in-situ drug release (Wu et al. 2020).
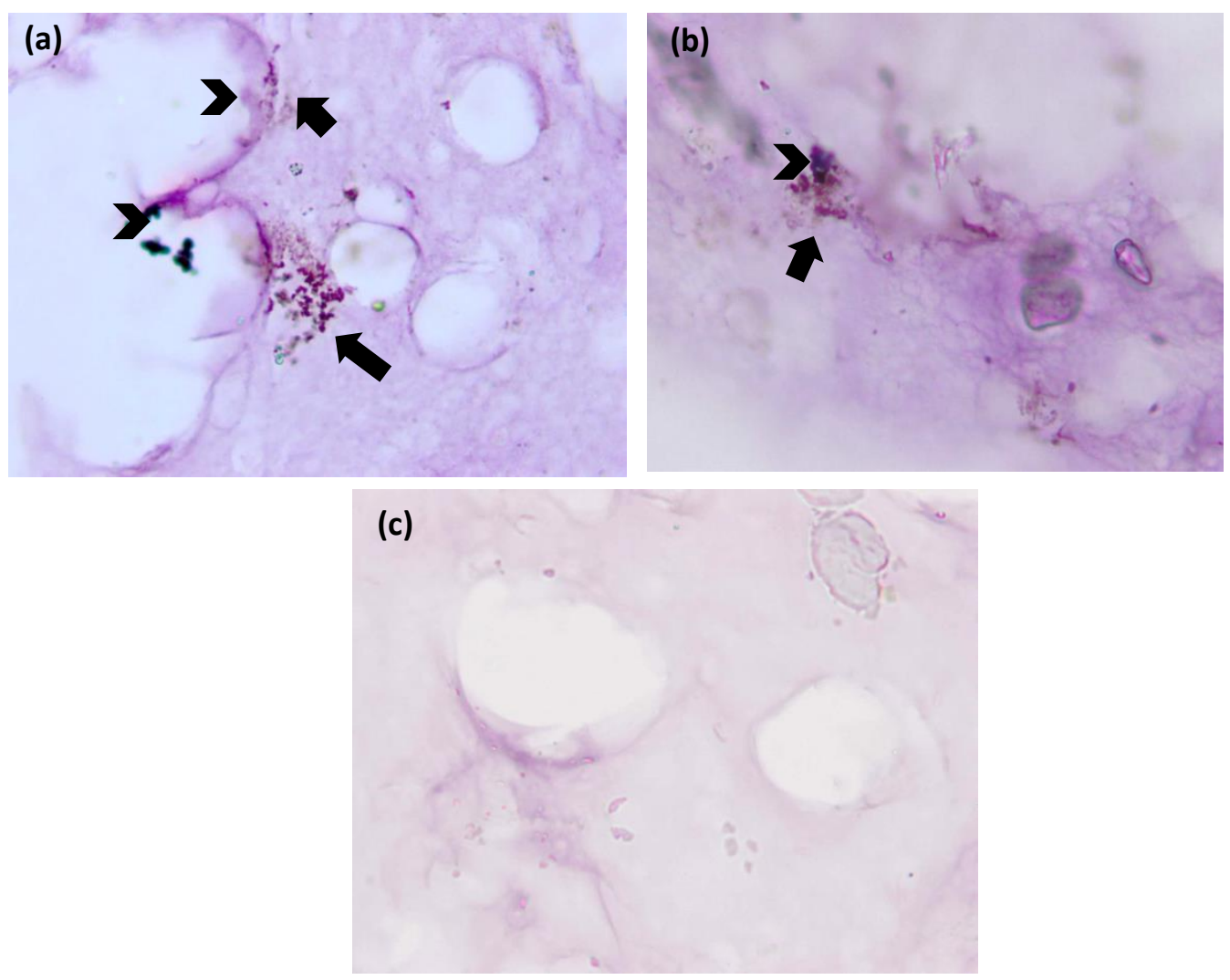

FIGURE 3. Microscopy observation of Staphylococcus epidermidis in control group (a), $3 \mathrm{wt} \%$ vancomycin (b) and $5 \mathrm{wt} \%$ vancomycin scaffold (c) using H\&E staining at $\times 100$ magnification (Black arrow-bacterial colony;

Arrowhead - biofilm) 

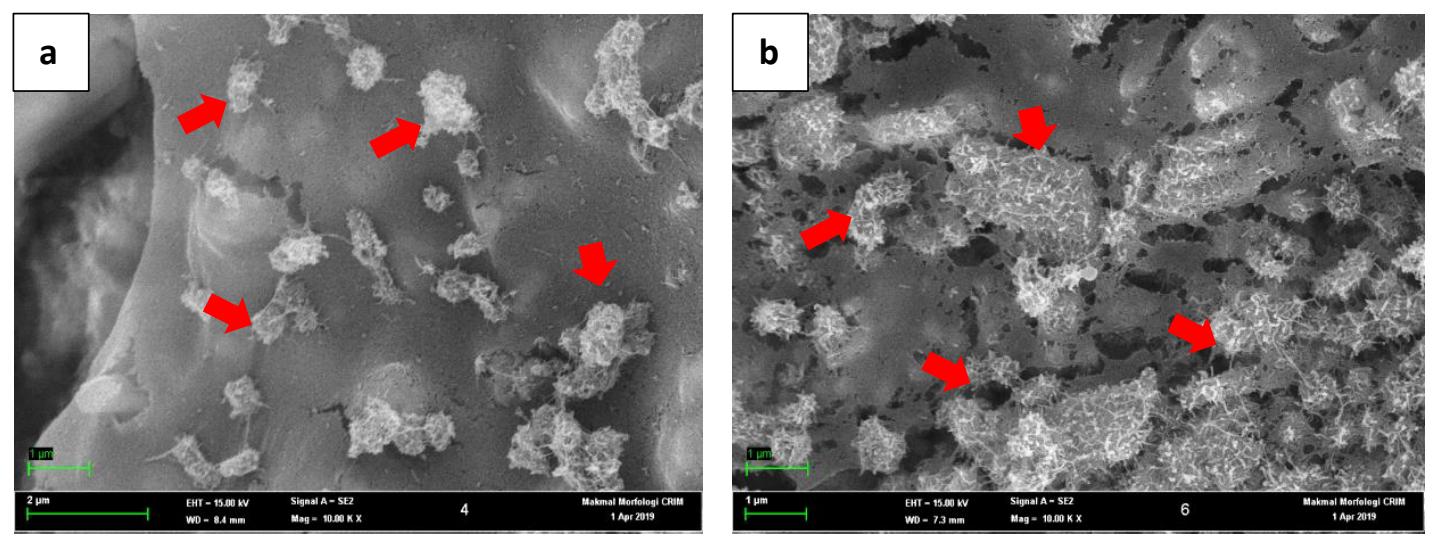

FIGURE 4. SEM micrograph of surface mineralization on control scaffold (a) and $5 \mathrm{wt} \%$ vancomycin loaded scaffold (b) at $\times 10000$ magnification (Arrow-

Mineral apatite)

\section{CONCLUSION}

The use of localized drug delivery systems reduces any potential effects of systemic toxicity that is caused with the use of high dosage administration of systemic drugs. Incorporation of drugs into an implant material also addresses the fast availability of drugs at the target site due to lack of vasculature in the bone. In this study, vancomycin was successfully incorporated into nanobiocomposite bone scaffold fabricated using alginate and nano cockle shell powder that showed antibacterial effects without alteration in the scaffolds mineralization characteristic. The antibacterial effect of the scaffold was also evident throughout the period of the study rendering a protective effect in support of the bone regeneration process and potentially reducing incidences of implant infections and rejections. Further studies are being done to observe the proliferation and growth of osteoblast on the scaffold in order to evaluate the potential use of this scaffold as an implant material and a local drug delivery system in the field of biomaterial-based bone tissue engineering.

\section{ACKNOWLEDGEMENTS}

The authors thank the Faculty of Health Sciences, Universiti Kebangsaan Malaysia (UKM) for supporting this study. This research was funded by the UKM University
Research Grant (Geran Universiti Penyelidikan (GUP) 2017 021). The authors declare that there is no conflict of interests regarding the publication of this paper.

\section{REFERENCES}

Abbasi, N., Hamlet, S., Love, R.M. \& Nguyen, N.T. 2020. Porous scaffold for bone regeneration. Journal of Science: Advanced Materials and Devices 5(1): 1-9.

Abdelfattah, M.I., Nasry, S.A. \& Mostafa, A.A. 2016. Characterization and cytotoxicity analysis of a ciprofloxacin loaded chitosan/bioglass scaffold on cultured human periodontal ligament stem cells: A preliminary report. Open Access Macedonian Journal of Medical Sciences 4(3): 461467.

Ahmad, N., Bharatham, H., Hamid, Z.A., Perimal, E.K. \& George, P. 2019. Functional performance evaluation of an alginate/nano-cockle shell powder nanobiocomposite bone scaffold with BMP-2. Bulletin of Materials Science 42(3): $1-10$.

Bharatham, B.H., Bakar, A., Zuki, M., Perimal, E.K., Yusof, L.M. \& Hamid, M. 2014. Development and characterization of novel porous $3 \mathrm{D}$ alginate-cockle shell powder nanobiocomposite bone scaffold. BioMed Research International 2014: 146723.

Cao, Z., Jiang, D., Yan, L. \& Wu, J. 2017. In vitro and in vivo drug release and antibacterial properties of the novel vancomycin-loaded bone-like hydroxyapatite/poly amino acid scaffold. International Journal of Nanomedicine 12: 1841-1851. 
Channasanon, S., Udomkusonsri, P., Chantaweroad, S., Tesavibul, P. \& Tanodekaew, S. 2017. Gentamicin released from porous scaffolds fabricated by stereolithography. Journal of Healthcare Engineering 2017: 9547896.

Cheung, G.Y., Rigby, K., Wang, R., Queck, S.Y., Braughton, K.R., Whitney, A.R., Teintze, M., Deleo, F.R. \& Otto, M. 2010. Staphylococcus epidermidis strategies to avoid killing by human neutrophils. PLoS Pathogens 6(10): e1001133.

Costa, P.F. 2015. Bone tissue engineering drug delivery. Curr. Mol. Bio. Rep. 1(2): 87-93.

del Pozo, E.G., Collazos, J., Carton, J.A., Camporro, D. \& Asensi, V. 2018. Factors predictive of relapse in adult bacterial osteomyelitis of long bones. BMC Infectious Diseases 18(1): $1-11$.

Dorozhkin, S.V. 2011. Self-setting calcium orthophosphate formulations: Cements, concretes, pastes and putties. International Journal of Materials and Chemistry 1(1): 1-48.

George, P., Hamid, Z.A., Zakaria, M.Z.A.B., Perimal, E.K. \& Bhatatham, H. 2019. A short review on cockle shells as biomaterials in the context of bone scaffold fabrication. Sains Malaysiana 48(7): 1539-1545.

Gentile, P., Bellucci, D., Sola, A., Mattu, C., Cannillo, V. \& Ciardelli, G. 2015. Composite scaffolds for controlled drug release: Role of the polyurethane nanoparticles on the physical properties and cell behaviour. Journal of the Mechanical Behavior of Biomedical Materials 44: 53-60.

Gimeno, M., Pinczowski, P., Pérez, M., Giorello, A., Martínez, M.Á., Santamaría, J., Arruebo, M. \& Luján, L. 2015. A controlled antibiotic release system to prevent orthopedicimplant associated infections: An in vitro study. European Journal of Pharmaceutics and Biopharmaceutics 96: 264271.

Gutiérrez-Prieto, S.J., Perdomo-Lara, S.J., Diaz-Peraza, J.M. \& Sequeda-Castañeda, L.G. 2019. Analysis of in vitro ostoeblast culture on scaffolds for future bone regeneration purposes in dentistry. Advances in Pharmacological and Pharmaceutical Sciences 2019: 5420752.

Hemabarathy, B., Md. Zuki, A.B.Z., Perimal, E.K., Yusof, L.Q. \& Hamid, M. 2014. Mineral and physiochemical evaluation of cockle shell (Anadara granosa) and other selected molluscan shell as potential biomaterials. Sains Malaysiana 43(7): 1023-1029.

Isa, T., Zakaria, Z.A.B., Rukayadi, Y., Mohd Hezmee, M.N., Jaji, A.Z., Imam, M.U., Hammadi, N.I. \& Mahmood, S.K. 2016. Antibacterial activity of ciprofloxacin-encapsulated cockle shells calcium carbonate (aragonite) nanoparticles and its biocompatability in macrophage J774A.1. International Journal of Molecular Sciences 17(5): 713.

Johnson, C.T. \& García, A.J. 2015. Scaffold-based anti-infection strategies in bone repair. Annals of Biomedical Engineering 43(3): 515-528.

Kohanski, M.A., Dwyer, D.J. \& Collins, J.J. 2010. How antibiotics kill bacteria: From targets to networks. Nature Reviews Microbiology 8(6): 423-435.
Krishnan, A.G., Jayaram, L., Biswas, R. \& Nair, M. 2015. Evaluation of antibacterial activity and cytocompatibility of ciprofloxacin loaded gelatin-hydroxyapatite scaffolds as a local drug delivery system for osteomyelitis treatment. Tissue Engineering Part A 21(7-8): 1422-1431.

Lecaroz, C., Gamazo, C. \& Blanco-Prieto, M. 2006. Nanocarriers with gentamicin to treat intracellular pathogens. Journal of Nanoscience and Nanotechnology 6(9-10): 32963302.

Leekha, S., Terrell, C.L. \& Edson, R.S. 2011. General principles of antimicrobial therapy. Mayo Clinic Proceedings 86(2): 156-167.

Luongo, F., Mangano, F.G., Macchi, A., Luongo, G. \& Mangano, C. 2016. Custom-made synthetic scaffolds for bone reconstruction: A retrospective, multicenter clinical study on 15 patients. BioMed Research International 2016 5862586.

Matsubayashi, M., Terukina, T., Hattori, Y. \& Otsuka, M. 2018. Preparation of calcium phosphate coated simvastatinloaded PLGA microspheres dispersed alginate hydrogel beads as a controlled drug delivery carrier. Key Engineering Materials 782(October): 201-206.

Montanaro, L., Speziale, P., Campoccia, D., Ravaioli, S., Cangini, I., Pietrocola, G., Giannini, S. \& Arciola, C.R. 2011. Scenery of staphylococcus implant infections in orthopedics. Future Microbiology 6(11): 1329-1349.

Mouriño, V. \& Boccaccini, A.R. 2010. Bone tissue engineering therapeutics: Controlled drug delivery in three-dimensional scaffolds. Journal of the Royal Society Interface 7(43): 209-227.

Parent, M., Magnaudeix, A., Delebassee, S., Sarre, E., Champion, E., Trecant, M.V. \& Damia, C. 2016. Hydroxyapatite microporous bioceramics as vancomycin reservoir: Antibacterial efficiency and biocompatibility investigation. Journal of Biomaterials Applications 31(4): 488-498.

Punyani, S., Deb, S. \& Singh, H. 2007. Contact killing antimicrobial acrylic bone cements: Preparation and characterization. Journal of Biomaterials Science, Polymer Edition 18(2): 131-145.

Ribeiro, M., Monteiro, F.J. \& Ferraz, M.P. 2012. Infection of orthopedic implants with emphasis on bacterial adhesion process and techniques used in studying bacterial-material interactions. Biomatter 2(4): 176-194.

Rodriguez, I., Saxena, G., Sell, S. \& Bowlin, G. 2014. Mineralization and characterization of composite lyophilized gelatin sponges intended for early bone regeneration. Bioengineering 1(1): 62-84.

Saravanan, S., Nethala, S., Pattnaik, S., Tripathi, A., Moorthi, A. \& Selvamurugan, N. 2011. Preparation, characterization and antimicrobial activity of a bio-composite scaffold containing chitosan/nano-hydroxyapatite/nano-silver for bone tissue engineering. International Journal of Biological Macromolecules 49(2): 188-193. 
Wu, X., Walsh, K., Hoff, B.L. \& Camci-Unal, G. 2020. Mineralization of biomaterials for bone tissue engineering. Bioengineering 7(4): 132.

Yang, Y.H., Wang, J.C. \& Pei, Y.L. 2011. Adding vancomycin to bone cement: Research on its influence on mechanical and fixation strength using rabbit femoral prostheses. Orthopaedic Surgery 3(4): 265-267.

Zhang, J., Wang, C., Wang, J., Qu, Y. \& Liu, G. 2012. In vivo drug release and antibacterial properties of vancomycin loaded hydroxyapatite/chitosan composite. Drug Delivery 19(5): 264-269.

Zhao, X., Kim, J., Cezar, C.A., Huebsch, N., Lee, K., Bouhadir, K. \& Mooney, D.J. 2011. Active scaffolds for on-demand drug and cell delivery. Proceedings of the National Academy of Sciences 108(1): 67-72.
Su Wen Yuan, Jacinta Santhanam \& B. Hemabarathy Bharatham* Biomedical Science Programme

Universiti Kebangsaan Malaysia

Jalan Raja Muda Abdul Aziz

50300 Kuala Lumpur, Federal Territory

Malaysia

Ng Shiow Fern

Faculty of Pharmacy

Universiti Kebangsaan Malaysia

Jalan Raja Muda Abdul Aziz

50300 Kuala Lumpur, Federal Territory

Malaysia

*Corresponding author; email: hema@ukm.edu.my

Received: 29 September 2020

Accepted: 12 December 2020 